\title{
The Bioavailability, Extraction, Biosynthesis and Distribution of Natural Dihydrochalcone: Phloridzin
}

\author{
Lei Tian $\left.{ }^{1}{ }^{(}\right)$, Jianxin Cao ${ }^{1}$, Tianrui Zhao ${ }^{1}$, Yaping Liu ${ }^{1}$, Afsar Khan ${ }^{2}$ and Guiguang Cheng ${ }^{1, *} \mathbb{C}$ \\ 1 Faculty of Agriculture and Food, Kunming University of Science and Technology, Kunming 650500, China; \\ leotian@kust.edu.cn (L.T.); jxcao321@hotmail.com (J.C.); food363@163.com (T.Z.); \\ yapingliu820203@163.com (Y.L.) \\ 2 Department of Chemistry, Abbottabad Campus, COMSATS University Islamabad, Abbottabad 22060, \\ Pakistan; afsarhej@gmail.com \\ * Correspondence: ggcheng@kust.edu.cn; Tel.: +86-158-8786-1273
}

check for

updates

Citation: Tian, L.; Cao, J.; Zhao, T.; Liu, Y.; Khan, A.; Cheng, G. The Bioavailability, Extraction,

Biosynthesis and Distribution of Natural Dihydrochalcone: Phloridzin. Int. J. Mol. Sci. 2021, 22, 962.

https://doi.org/10.3390/ijms22020962

Received: 24 December 2020

Accepted: 17 January 2021

Published: 19 January 2021

Publisher's Note: MDPI stays neutral with regard to jurisdictional claims in published maps and institutional affiliations.

Copyright: (c) 2021 by the authors. Licensee MDPI, Basel, Switzerland. This article is an open access article distributed under the terms and conditions of the Creative Commons Attribution (CC BY) license (https:// creativecommons.org/licenses/by/ $4.0 /)$

\begin{abstract}
Phloridzin is an important phytochemical which was first isolated from the bark of apple trees. It is a member of the dihydrochalcones and mainly distributed in the plants of the Malus genus, therefore, the extraction method of phloridzin was similar to those of other phenolic substances. High-speed countercurrent chromatography (HSCCC), resin adsorption technology and preparative high-performance liquid chromatography (HPLC) were used to separate and purify phloridzin. Many studies showed that phloridzin had multiple pharmacological effects, such as antidiabetic, antiinflammatory, antihyperglycaemic, anticancer and antibacterial activities. Besides, the physiological activities of phloridzin are cardioprotective, neuroprotective, hepatoprotective, immunomodulatory, antiobesity, antioxidant and so on. The present review summarizes the biosynthesis, distribution, extraction and bioavailability of the natural compound phloridzin and discusses its applications in food and medicine.
\end{abstract}

Keywords: phloridzin; pharmacological activities; physiological effects; medicine; food

\section{Introduction}

Natural products, especially from medicinal plants or herbs, have played a key role in human health and welfare. According to their chemical structures, they are usually classified as polyphenols (e.g., flavonoids, lignans, stilbenes, phenolic acids), alkaloids, sterols, terpenoids, polysaccharides and so on. These diverse phytochemical groups exhibit an extensive range of human health benefits, and are important sources of useful bioactive compounds. In fact, some of them have been taken as lead compounds for structural modifications or developed as modern clinical drugs. In addition, plant-based foods provide us with essential nutrients and contribute to a remarkable portion of our daily diets, including fruits, vegetables, beans, grains and nuts. Extensive studies have demonstrated that these diets are rich in dietary phytochemicals, which are recognized for their health benefits or medicinal properties as nutraceuticals. Recently, more and more people wish to consume the foods containing nutraceuticals for the improvement of the quality of human life and with the desired health potentials rather than to take medicine for illness prevention.

In the last two decades, many researchers focused on the isolation and identification of phytochemicals with novel structures and unique biological activities, but only $15 \%$ of them have been analyzed phytochemically, and only $6 \%$ have been used in biological screens [1]. To date, natural compounds have been widely used for keeping good health and treating various diseases, as agents of dietary supplements and pharmaceuticals. Lots of experimental results have demonstrated that natural products have various promising activities, such as antioxidant, anti-inflammatory, antimicrobial, antidiabetic, antiseptic, spasmolytic, sedative, hepatoprotective and immunomodulatory activities [2-4]. Moreover, 
numerous phytochemicals with a large range of biological and pharmacological activities have been extracted and identified from natural plants.

Apple is one of the most commonly consumed fruits all over the world, and is a good source of polyphenols. There is a lot of evidence that frequent apple consumption contributes to human health, because polyphenols in apple have lots of beneficial biological functions, and phloridzin is one of polyphenols [5]. Phloridzin, also known as phlorizoside or phlorrhizin, belongs to the class of organic compounds which are known as flavonoid $\mathrm{O}$-glycosides. Flavonoid O-glycosides are compounds containing a carbohydrate moiety, which is O-glycosidically linked to the 2-phenylchromen-4-one flavonoid backbone. Phloridzin (also referred to as phlorizin; chemical name phloretin- $2^{\prime}-O-\beta$-D-glucopyranoside) is a glucoside of phloretin, a member of dihydrochalcone, a family of bicyclic flavonoids, and a monosaccharide derivative [6], which in turn is a subgroup in the diverse phenylpropanoid synthesis pathway in plants. Phloridzin is an extremely weak basic (essentially neutral) and bitter-tasting compound, with a molecular weight of $436.4 \mathrm{~g} / \mathrm{mol}$ and the molecular formula $\mathrm{C}_{21} \mathrm{H}_{24} \mathrm{O}_{10}$ (Figure 1: 1-Propanone, 1-[2-( $\beta$-D-glucopyranosyloxy)-4,6dihydroxyphenyl]-3-(4-hydroxyphenyl)-).<smiles>O=C(CCc1ccc(O)cc1)c1c(O)cc(O)cc1OC1OC2OC1C(O)C(O)C(O)C2O</smiles>

Figure 1. The structure of phloridzin.

In 1835, a French scientist first isolated phloridzin from the bark of apple trees [7]. Phloridzin was previously considered a candidate for the treatment of fever, infectious diseases and malaria at that time [8]. Decades later, it was discovered that phloridzin could inhibit renal glucose reabsorption and causes glucosuria [9]. Some studies revealed that phloridzin was a competitive inhibitor of sodium-glucose cotransporters SGLT1 and SGLT2, because it could bind with the carrier that competed with D-glucose and, consequently, this reduced renal glucose transport, increased urinary glucose excretion and ameliorated plasma glucose concentration [10-12]. For decades, an enormous number of studies have been carried out on the pharmacological activities and physiological effects of phloridzin and its derivatives. This review aims to exhaustively sum up phloridzin's biosynthesis, distribution, extraction and physiological and pharmacological effects.

\section{Biosynthesis and Distribution of Phloridzin}

The biosynthesis of phloridzin is different from general flavonoids, and its precursors are malonyl-CoA and p-coumaroyl-CoA. First, p-coumaroyl-CoA generates 4hydroxydihydrocinnamoyl-CoA via the NADPH pathway, then malonyl-CoA and 4hydroxydihydrocinnamoyl-CoA produce phloretin under the action of chalcone synthase, and the attachment of a glucose moiety to phloretin at position $2^{\prime}$ is the final step in the formation of phloridzin [13]. Two glycosyltransferases (both MdUGT88F1 and its paralog MdUGT88F4) convert phloretin to phloridzin in Malus plants [14,15]. Experimental evidence suggests that enoyl reductase-like genes-3 (ENRL-3) and ENRL-5 might contribute to the biosynthesis of phloridzin in apple [16].

Phloridzin is a member of the chalcone class of organic compounds and is mainly distributed in the plants of the Malus genus, although other plant species are described as containing phloridzin (Table 1). In humans, phloridzin is involved in lactose degradation. In addition, phloridzin is usually detected in higher concentrations in some foods, such as Mexican oregano, European plums and apples, while in pomegranates and apricots, it is found in lower concentrations. Phloridzin has also been found in several other foods 
such as epazotes, durians, Chinese broccoli, sesame and sweet potatoes. This could make phloridzin a potential biomarker for the consumption of these foods.

Table 1. Phloridzin-containing plant species.

\begin{tabular}{|c|c|c|c|}
\hline Plant species & Tissue & Extraction Solvent & References \\
\hline Acanthopanax senticosus & Root & Methanol & [17] \\
\hline Acca sellowiana & Flesh & Methanol & [18] \\
\hline Aspalathus linearis & Leaf & Methanol and Water (1\% Formic acid) & [19] \\
\hline Aspalathus pendula & Leaf & Methanol and Water (1\% Formic acid) & [19] \\
\hline Berberis jaeschkeana & Flesh & Methanol & [20] \\
\hline Camellia japonica & Leaf & Water & [21] \\
\hline Docynia dcne & Leaf & Methanol and Acetonitrile & [22] \\
\hline Docynia indica & Leaf & $\begin{array}{c}\text { Ethyl acetate, } \mathrm{n} \text {-hexane, n-butanol and } \\
\text { Methanol }\end{array}$ & [23] \\
\hline $\begin{array}{l}\text { Eleutherococcus } \\
\text { senticosus }\end{array}$ & Root & Methanol & [24] \\
\hline Fragaria $x$ ananassa & Flesh & Acetone & [25] \\
\hline Glycine max & Seed & Ethanol & [26] \\
\hline Hemerocallis $x$ hybrida & Flower & Hexane, Ethyl acetate and Methanol & [27] \\
\hline Lactuca sativa & Flesh & Water & [28] \\
\hline Lithocarpus polystachyus & Leaf & Ethanol, Methanol & [29-32] \\
\hline Lippia graveolens & Leaf & Methanol & [33] \\
\hline Nelumbo nucifera & Seed & Ethanol & [34] \\
\hline Pisum sativum & Seed & Acetone & [35] \\
\hline Polygonum cuspidatum & Flower & Methanol & [36] \\
\hline Prunus persica & Flesh & Methanol and Water with Formic acid & [37] \\
\hline Psidium guajava & Peel and Flesh & Methanol and Water with Formic acid & [38] \\
\hline Punica granatum & Flesh & - & [39] \\
\hline Pyrus pashia & Flesh & Ethanol & [40] \\
\hline Rosa canina & Flesh & Methanol and Water with Formic acid & [41] \\
\hline Rubus occidentalis & Flesh & Methanol & [42] \\
\hline Solanum lycopersicum & Flesh & Methanol & [43] \\
\hline Sechium edule & Flesh & Methanol & [44] \\
\hline Vaccinium vitis-idaea & Flesh & $\begin{array}{l}\text { Methanol, Ethanol, Formic acid, } \\
\text { Acetone, Ethyl acetate, Water, }\end{array}$ & [45] \\
\hline Vaccinium macrocarpon & Flesh & Methanol & [46] \\
\hline
\end{tabular}

\section{Extraction, Separation and Purification of Phloridzin}

Phloridzin is solid at room temperature and poorly soluble in ether and cold water but soluble in ethanol and hot water, the melting point of phloridzin is $110^{\circ} \mathrm{C}$ and it decomposes above $200{ }^{\circ} \mathrm{C}$. Phloridzin's extraction method is similar to that of other phenolic substances. Alberti et al. [47] reported that response surface methodology is an adequate approach for phloridzin extraction from apples, and phloridzin had higher yields (48.4\%) in extractions with methanol. Zhang et al. [48] found that an ultrasound-assisted aqueous two-phase extraction strategy had significant advantages, including lower ethanol consumption, lower impurity of sugar and protein and higher extraction efficiency of phloridzin than the traditional solvent extraction with 35\% and 80\% ethanol. Paudel et al. [42] reported that phloridzin of black raspberry (Rubus occidentalis L.) fruits was extracted in ethyl acetate, isolated by semipreparative analytical HPLC and analyzed by nuclear magnetic resonance (NMR), HPLC-electrospray ionization mass spectrometry (ESI-MS) and ESI-MS/MS techniques.

At present, chemical extraction, high-speed countercurrent chromatography (HSCCC), resin adsorption technology and preparative HPLC methods are mainly used to separate and purify phloridzin. Dong et al. [32] separated, analyzed and identified 99.87\% pure phloridzin from the crude extract of Lithocarpus polystachyus by thin layer chromatography (TLC) and HPLC-ESI-MS. Fromm et al. [49] reported that resin adsorption technology was a very effective tool for further purification as well as for the selective enrichment 
of phloridzin from apple seeds. Sun et al. [50,51] found that X-5 resin and polyamide resin were feasible and effective methods for the separation and purification of phloridzin from thinned young apples. Liang et al. [52] found that the HSCCC-HPLC-diode array detector-mass spectrometry (HSCCC-HPLC-DAD-MS) method served as a simple, rapid and effective way to achieve phloridzin with high purity (over 99\%) from Malus doumeri leaves. Gao et al. [53] demonstrated that the prepared magnetic molecularly imprinted polymers (MMIPs) were suitable for phloridzin's selective adsorption from complex samples such as natural medical plant extracts and biological samples. Li et al. [54] reported that macroporous resin followed by a preparative HPLC method was used for the purification of phloridzin from apple leaves; the phloridzin purity reached above $98 \%$ after further recrystallization with a recovery yield of $75.8 \%$.

\section{Therapeutic Properties of Phloridzin}

Extensive research on phloridzin has been conducted for all kinds of purposes in medicine and biology since it was discovered in the bark of apple trees.

\subsection{Antihyperglycemic Effect}

Phloridzin improved hyperglycemia without altering insulin secretion in diabetic rats [55,56], because it could inhibit intestinal glucose uptake via sodium-dependent glucose transporters (SGLTs) and similarly control renal glucose reabsorption [57-59]. Malatiali et al. [60] reported that phloridzin induced normalization of blood glucose and prevented proteinuria, hyperfiltration and kidney hypertrophy, but not glomerular hypertrophy, in diabetic rats. Masumoto et al. [61] found that dietary phloridzin decreased the overexpression of SGLT1, cytochrome P450 2b10 (Cyp2b10) and epoxide hydrolase 1 (Ephx1) in the small intestine of diabetic mice and, accordingly, improved abnormal elevations in blood glucose levels. Osorio et al. [62] reported that phloridzin treatment reduced hyperglycemia, normalized hypertension and inhibited SGLT2 activity but did not modify SGLT2 expression in brush border membrane vesicles. Kobori et al. [63] revealed that dietary phloridzin significantly suppressed blood glucose levels, however, high continuous intakes of phloridzin reduced hepatic gene expressions related to metabolism, such as the citrate cycle, gluconeogenesis, fatty acid metabolism and branched chain amino acid metabolism in healthy mice. Najafian et al. [64] reported that phloridzin not only reduced blood glucose levels, but also improved lipid metabolism in streptozotocin-induced diabetic rats. Makarova et al. [65] demonstrated that unripe apple preparation containing phloridzin reduced postprandial glycemia and improved the health of diabetic patients. Mei et al. [66] found that phloridzin normalized the hyperglycemia of type 2 diabetes $(\mathrm{db} / \mathrm{db})$ mice by a decrease in serum lipopolysaccharides and gut microbiota changes. Wang et al. [67] reported that phloridzin accelerated liver glycogen synthesis, decreased hepatic gluconeogenesis and had hypoglycemic effects in type 2 diabetes mellitus mice. Lv et al. [68] reported that phloridzin from tea crabapple (Malus hupehensis) had a significant concentration-dependent inhibitory effect on $\alpha$-glucosidase in vitro.

Despite the antihyperglycemic effects of phloridzin, it has some limitations, including poor absorption, rapid degradation and low bioavailability [7]. Phloridzin itself is not developed as a drug but, currently, some phloridzin-derived SGLT2 inhibitors (dapagliflozin, canagliflozin, empagliflozin, ertugliflozin, tofogliflozin and luseogliflozin) have gained approval in some developed countries [10].

\subsection{Antioxidant Activity}

Phloridzin acts as natural antioxidant, scavenges free radicals, inhibits lipid peroxidation, increases the activities of antioxidant enzymes and prevents oxidative stress (Table 2). Ma et al. [34] reported that the extracts from lotus seed epicarp (containing phloridzin) have antioxidant activity, which was identified by 2,2-diphenyl-1-picrylhydrazyl (DPPH) and 2,2-azino-bis(3-ethylbenzothiazoline-6-sulphonic acid) (ABTS) radical-scavenging methods. Similarly, Xiao et al. [69] demonstrated that phloridzin of Malus domestica exhibited antioxi- 
dant capacity by DPPH and ABST assays. Liaudanskas et al. [70] reported that apple leaf ethanol extract (phloridzin was the major compound) possessed strong antioxidant activity by ABTS, DPPH and ferric-reducing antioxidant power (FRAP) assays.

Table 2. Antioxidant effects of phloridzin.

\begin{tabular}{cccc}
\hline Plant Species & Tissue & Experimental Assays & References \\
\hline Eleutherococcus senticosus & Root & 2,2-diphenyl-1-picrylhydrazyl (DPPH) & [24] \\
Malus domestica & Peel & Thiobarbituric acid reactive substance (TBARS) assay & [72] \\
Malus domestica & Leaf & 2,2-azino-bis(3-ethylbenzothiazoline-6-sulphonic acid) & [70] \\
Malus domestica & (ABTS), DPPH, Ferric-reducing antioxidant power (FRAP) & [69] \\
Malus domestica & Flesh (thinned young) & ABTS, DPPH & 775] \\
Malus toringoides & Leaf & TBARS & [74] \\
Nelumbo nucifera & Seed & ABTS, DPPH, FRAP & [34] \\
& & ABTS, DPPH, FRAP & TBARS \\
& & Paraquat challenge assay, & [73] \\
\hline
\end{tabular}

In addition to free radical-scavenging properties, phloridzin has been identified as a potent antioxidant in the inhibition of lipid peroxidation. Rupasinghe and Yasmin [71] reported that phloridzin had a significant effect in preventing peroxyl radical-induced oxidation by polyunsaturated fatty acid in aqueous emulsions. Thilakarathna et al. [72] found that phloridzin extracted from apple peel effectively inhibited human low density lipoprotein (LDL) cholesterol oxidation in vitro. Wang et al. [73] demonstrated that apple phloridzin extended the life span, improved the viability, alleviated the mortality rate induced by paraquat and $\mathrm{H}_{2} \mathrm{O}_{2}$ and increased the activity of antioxidant enzymes in fruit flies. Fan et al. [74] found that phloridzin was the main component of $\mathrm{E}$ Se tea extracts, which significantly prevented oxidative stress damage and reduced the apoptosis of $\mathrm{H}_{2} \mathrm{O}_{2}$ induced HepG2 cells.

The antioxidant activity of phloridzin was associated with other biological properties. Choi et al. [24] revealed that phloridzin had antioxidant activity, which affected stem cell fate in the skin via the inhibition of miR135b and following the synthesis of type IV collagen of the basement membrane. Sun et al. [75] reported that young apple polyphenols, mainly composed of phloridzin, showed strong antioxidant activity in vitro and a preservative effect on grass carp surimi during cold storage.

\subsection{Anti-Inflammatory Effects}

The anti-inflammatory activity of phloridzin has been investigated in some laboratorybased studies (Table 3). Shin et al. [76] found that phloridzin suppressed plasma proinflammatory adipokine levels and, furthermore, attenuated inflammation in diet-induced obese mice. Zhao et al. [77] reported that phloridzin metabolites decreased nitric oxide (NO) production and the expression of inducible nitric oxide synthase (iNOS) in lipopolysaccharide (LPS)-stimulated RAW264.7 cells, which showed anti-inflammatory activity. Zielinska et al. [78] demonstrated that apple phloridzin improved the quality of anti-inflammatory response in the intestine and, accordingly, ameliorated cytokine-driven inflammation. Chang et al. [79] reported that the metabolite of phloridzin suppressed the inflammatory response in RAW264.7 murine macrophages that had been stimulated by LPS from Gram-negative bacteria. Zhai et al. [80] showed that phloridzin decreased the expression of ultraviolet B (UVB)-induced pro-inflammatory cytokines and reduced acute inflammation infiltration in UVB-exposed skin. Tian et al. [81] showed that phloridzin significantly reduced the concentration of serum and adipose tissue pro-inflammatory cytokines and attenuated adipose tissue inflammation in high-fat diet (HFD)-fed mice. 
Table 3. Anti-inflammatory effects of phloridzin.

\begin{tabular}{|c|c|c|}
\hline Experimental Model & Inflammatory Index Assays & References \\
\hline Diet-Induced Obese Mice & $\begin{array}{l}\text { Tumor Necrosis Factor- } \alpha \text { (TNF- } \alpha) \text {, Monocyte Chemoattractant Protein-1 } \\
\text { (MCP-1), Interferon- } \gamma \text { (IFN- } \gamma) \text {, Interleukin-6 (IL-6), Leptin, Adipsin }\end{array}$ & {$[76]$} \\
\hline LPS-Stimulated RAW 264.7 Cells & Nitric Oxide (NO), Inducible Nitric Oxide Synthase (iNOS), TNF- $\alpha$, IL-10 & [77] \\
\hline IL-1 $\beta$-Stimulated Myofibroblasts & $\begin{array}{l}\left.\text { Prostaglandin E2 ( } \mathrm{PGE}_{2}\right) \text {, Intercellular Cell Adhesion Molecule-1 (ICAM-1), } \\
\text { IL-8, IL-6, MCP-1 }\end{array}$ & [78] \\
\hline LPS-Stimulated RAW 264.7 Cells & Cyclooxygenase-2 (Cox-2), NO, PGE2, IL-6, TNF- $\alpha$, iNOS & [79] \\
\hline $\begin{array}{l}\text { UVB-Induced Mouse Skin Damage, } \\
\text { UVB-Induced HaCaT Cells }\end{array}$ & Reactive Oxygen Species (ROS), IL-1 $\beta$, IL-6, IL-8, Cox-2 & {$[80]$} \\
\hline Diet-Induced Obese Mice & MCP-1, TNF- $\alpha$, IL-1, IL-6, IL-1 $\beta$ & [81] \\
\hline
\end{tabular}

\subsection{Hepatoprotective Effects}

Many reports suggested that phloridzin has a hepatoprotective function by regulating lipid metabolism and oxidative stress and inhibiting hepatic inflammation and apoptosis. Lu et al. [82] found that phloridzin decreased body weight gain and the levels of glucose, blood total cholesterol (TC) and blood triglycerides (TG) in blood and, accordingly, ameliorated the hepatic damage of type 2 diabetic mice. Shin et al. [76] reported that phloridzin also alleviated hepatic steatosis, inflammation and fibrosis by decreasing white adipose tissue and collagen accumulation. Khalifa et al. [83] elucidated the protective effects of phloridzin against methotrexate-induced hepatic injury in rats by the mitigation of oxidative stress, inflammation and apoptosis in hepatic tissues. Parathodi Illam et al. [84] reported that a combination of aqueous extracts of fruits (containing phloridzin) improved hepatic and renal glutathione peroxidase (GPx), superoxide dismutase (SOD) and catalase activities and glutathione (GSH) levels in normal Swiss albino mice. Wang et al. [85] demonstrated that apple phloridzin increased cell viability, relieved deoxyribonucleic acid (DNA) damage, oxidative stress and apoptosis in $\mathrm{H}_{2} \mathrm{O}_{2}$-induced HepG2 cells by the nuclear factor E2-related factor 2 (Nrf2) signaling pathway and anti-apoptosis genes. David-Silva et al. [86] found that phloridzin restored glycemic control and hepatic glucose metabolism, inhibited hepatic glucose production and ameliorated non-alcoholic fatty liver disease in type 2 diabetic mice.

\subsection{Antitumor Effects}

Phloridzin was utilized to trigger cancer cell death through either direct or indirect pathways. Qin et al. [87] showed that phloridzin from crabapple leaves had antitumor effects and, moreover, its derivatives had a stronger protective effect against the four tested tumor cell lines, which suggested that phloridzin and its derivatives could be considered as possible therapeutic agents against cancer. Aguiniga-Sanchez et al. [44] reported that a fruit methanol extract of Sechium edule var. nigrum spinosum contained phloridzin, and the extract eliminated tumor cells while protecting normal bone marrow cells.

\subsection{Antibacterial Activity}

In some experimental models, phloridzin exhibited antibacterial and antifungal activity. Sowa et al. [88] observed that extracts of Malus domestica leaves (containing a large amount of phloridzin) had antibacterial and antifungal activity by the inhibition of Staphylococcus aureus and Enterococcus faecalis and the fungus Candida glabrata. Lopes et al. [89] found that phloridzin was effective in inhibiting biofilm formation in Staphylococcus aureus strains, which increased efflux protein genes. Oleszek et al. [90] reported that extracts of apple pomace (fraction containing phloridzin) had antifungal activity by the inhibition of mycotoxigenic fungal growth. 


\subsection{Cardioprotective Effects}

Phloridzin was efficient in protecting the heart in certain diseases. Lee et al. [26] reported that extracts of Glycine max seed coat contained a large amount of phloridzin, and the extracts attenuated the adhesion of THP- 1 to LPS-stimulated human umbilical vascular endothelial cells, which suggested that phloridzin was a potential coronary heart disease preventive agent. Cai et al. [91] identified differentially expressed proteins involved in cardiac lipid metabolism, mitochondrial function and cardiomyopathy by isobaric tags for relative and absolute quantitation (iTRAQ) proteomics, which implied that phloridzin may prevent the development of diabetic cardiomyopathy by regulating the expression of key proteins in these processes. Hirose et al. [92] indicated that phloridzin prevented ischemiainduced ventricular tachyarrhythmia through the improvement of impulse conduction slowing during ischemia in Langendorff-perfused guinea pig hearts.

\subsection{The Effects of Phloridzin on Bone}

In addition to those activities discussed above, phloridzin also exhibited a capacity to improve bone in vivo. Puel et al. [93] reported that phloridzin was able to elicit protective effects on bone loss in osteoporosis in relation to inflammation. Antika et al. [94] reported that phloridzin and phloretin could promote osteoblastogenic bone formation through activating canonical glycogen synthase kinase $3 \beta$ (GSK-3 $\beta$ ) / $\beta$-catenin signaling involving runt-related transcription factor 2 (Runx2) in cell-based and aged mouse models. Londzin et al. [95] found that phloridzin $(20 \mathrm{mg} / \mathrm{kg})$ significantly increased unfavorable effects on the muscle and decreased the growth of bones, whereas it $(50 \mathrm{mg} / \mathrm{kg}) \mathrm{did}$ not affect most of the detected musculoskeletal parameters in type 2 diabetic rats.

\subsection{Other Effects}

Phloridzin had been reported to have a variety of other biological activities. Andlauer et al. [96] found that the natural substance phloridzin (present in apples) improved genistin absorption in isolated rat small intestine. Jung et al. [97] demonstrated that phloridzin acted through the cAMP pathway to increase tyrosinase transcriptional activities, thereby leading to the stimulation of melanogenesis. Gatidis et al. [98] revealed that a novel effect of phloridzin was the blunting of eryptosis, following energy depletion and oxidative stress. Xiang et al. [99] presented evidence that phloridzin had antiaging effects on yeast by increasing the activity of superoxide dismutase (SOD) and SIRT1. Wang et al. [100] reported that phloridzin inhibited polycystic kidney disease progression by the MAPK signaling pathway in a rat model. Pei et al. [101] revealed that phloridzin may be a renal protective agent by regulating differentially expressed proteins, which not only affected glomerular dysfunction and tubular transport, but also played active roles in oxidative stress and lipid metabolism. Wang et al. [102] demonstrated that phloridzin increased plasma lipoprotein lipase activity, and improved triglyceride metabolism via the adenosine 5'-monophosphate (AMP)-activated protein kinase (AMPK) pathway in stress-loaded mice. Wang et al. [103] found that extracts from the fruits of Malus baccata contained phloridzin, and the extracts had radioprotective and immunomodulatory activities. Kanda et al. [104] found that phloridzin strongly decreased high $\mathrm{K}^{+}$-induced contraction in phasic muscle (tenia coli), but slightly affected tonic muscle (trachea) because of the inhibition of energy metabolism via SGLT1. Li et al. [105] found that phloridzin increased NO output, suppressed SGLT1 and SGLT2 expression, and promoted the consumption of glucose, which ameliorated endothelial dysfunction by the phosphatidylinositol 3-kinase (PI3K)/protein kinase B (AKT)/endothelial nitric oxide synthase (eNOS) signaling pathway in palmitic acid-induced human umbilical vein endothelial cells. Kumar et al. [106] reported that phloridzin abrogated the Cdk5-mediated phosphorylation of peroxisome proliferator activated-receptor $\gamma$ (PPAR $\gamma$ ) at the ser273 site by strongly inhibiting Cdk5 activation, which increased insulin sensitivity and glucose uptake in differentiated adipocytes. Park et al. [107] found that phloridzin treatment resulted in the enhancement of erectile 
function, which was similar to that seen with insulin therapy, but phloridzin did not show anabolic effects, such as weight gain, in diabetic rats.

These studies showed that phloridzin had multiple pharmacological activities, such as antidiabetic, anti-inflammatory, antihyperglycemic, anticancer and antibacterial activities. Besides, the physiological effects of phloridzin are cardioprotective, neuroprotective, hepatoprotective, immunomodulatory, antiobesity, antioxidant activities and so on (Table 4, Figure 2).

Table 4. Therapeutic properties of phloridzin.

\begin{tabular}{|c|c|c|c|c|}
\hline Type & $\begin{array}{c}\text { Therapeutic } \\
\text { Properties }\end{array}$ & Methods & Main Findings & References \\
\hline \multirow{6}{*}{$\begin{array}{c}\text { Pharmacological } \\
\text { effects }\end{array}$} & Antihypertension & $\begin{array}{c}\text { Phloridzin }(0.4 \mathrm{~g} / \mathrm{kg} \text { body } \\
\text { weight } / \text { day) was given for } 4 \\
\text { weeks in propylene glycol } \\
\text { solution ( } 20 \%) \text { by subcutaneous } \\
\text { administration. }\end{array}$ & $\begin{array}{l}\text { Phloridzin treatment prevented } \\
\text { the development of } \\
\text { hypertension, decreased SGLT2 } \\
\text { activity in diabetic rats. }\end{array}$ & [62] \\
\hline & Antidiabetic & $\begin{array}{l}\text { Phloridzin (purity }>98 \% \text { ) was } \\
\text { given daily in sterile saline } \\
\text { solution ( } 20 \mathrm{mg} / \mathrm{kg} \text { body weight) } \\
\text { by intragastric administration. }\end{array}$ & $\begin{array}{l}\text { Phloridzin normalized } \\
\text { hyperglycemia of type } 2 \text { diabetic } \\
(\mathrm{db} / \mathrm{db}) \text { mice by serum } \\
\text { lipopolysaccharide decrease and } \\
\text { gut microbiota change. }\end{array}$ & [66] \\
\hline & Antihyperglycemic & $\begin{array}{l}\text { Phloridzin (100 mg) was isolated } \\
\text { from the leaves of Malus } \\
\text { hupehensis by preparative HPLC } \\
\text { with elution } 30 \% \text { acetonitrile } \\
\text { (ACN) and } 0.1 \% \text { acetic acid } \\
\text { (HAc). }\end{array}$ & $\begin{array}{l}\text { Phloridzin showed significant } \\
\text { concentration-dependent } \\
\text { inhibitory effects on } \\
\alpha \text {-glucosidase. }\end{array}$ & [68] \\
\hline & Anti-inflammatory & $\begin{array}{l}\text { Phloridzin (16.4-84.11 and } \\
\text { 6.6-45.1 } \mu \mathrm{g} / \mathrm{g} \text { formula weight } \\
\text { (FW) in peel and flesh, } \\
\text { respectively) was identified by } \\
\text { high-performance liquid } \\
\text { chromatography-diode array } \\
\text { detector-tandem mass } \\
\text { spectrometry } \\
\text { (HPLC-DAD-MS/MS) analysis } \\
\text { in the peel and flesh of different } \\
\text { apple cultivars. }\end{array}$ & $\begin{array}{l}\text { Phloridzin improved the quality } \\
\text { of anti-inflammatory response at } \\
\text { the intestinal level and, } \\
\text { accordingly, ameliorated } \\
\text { cytokine-driven inflammation. }\end{array}$ & [78] \\
\hline & Antitumor & $\begin{array}{l}\text { Phloridzin was isolated from the } \\
\text { leaves of Malus crabapples by } \\
\text { preparative HPLC. }\end{array}$ & $\begin{array}{l}\text { 3-(4,5-dimethylthiazol-2-yl)-2,5- } \\
\text { diphenyl tetrazolium bromide } \\
\text { (MTT) cancer cell growth } \\
\text { inhibition assay demonstrated } \\
\text { that phloridzin from crabapple } \\
\text { leaves had an antitumor effect. }\end{array}$ & [87] \\
\hline & Antimicrobial & $\begin{array}{c}\text { Phloridzin (above } 500 \mathrm{mg} \text { per } \mathrm{g} \\
\text { of ethyl acetate extract from the } \\
\text { leaves of Malus domestica) was } \\
\text { identified by HPLC. }\end{array}$ & $\begin{array}{c}\text { Antimicrobial activity was } \\
\text { observed for ethyl acetate extract } \\
\text { against strains of Staphylococcus } \\
\text { aureus ATCC } 25923 \text {, Enterococcus } \\
\text { faecalis ATCC } 29212 \text { and Candida } \\
\text { glabrata ATCC } 90030 .\end{array}$ & [88] \\
\hline
\end{tabular}


Table 4. Cont.

\begin{tabular}{|c|c|c|c|c|}
\hline Type & $\begin{array}{c}\text { Therapeutic } \\
\text { Properties }\end{array}$ & Methods & Main Findings & References \\
\hline \multirow{8}{*}{$\begin{array}{c}\text { Physiological } \\
\text { activities }\end{array}$} & Neuroprotective & $\begin{array}{l}\text { Phloridzin }(3.0-300.0 \mu \mathrm{g} / \mathrm{kg}) \\
\text { was dissolved in saline before } \\
\text { being used and was given } \\
\text { intraperitoneally. }\end{array}$ & $\begin{array}{l}\text { Phloridzin influenced memory } \\
\text { storage, but not memory } \\
\text { retrieval. }\end{array}$ & [57] \\
\hline & Antioxidant & $\begin{array}{l}\text { Phloridzin }(534 \pm 8.31 \mu \mathrm{g} / \mathrm{g}) \text { in } \\
\text { a crude extract of E Se tea was } \\
\text { identified and quantified using a } \\
\text { ultra-high-performance liquid } \\
\text { chromatography coupled with } \\
\text { tandem mass spectrometry } \\
\text { (UHPLC-ESI-HR-MS/MS). }\end{array}$ & $\begin{array}{l}\text { Phloridzin significantly } \\
\text { prevented oxidative stress } \\
\text { damage and reduced the } \\
\text { apoptosis of } \mathrm{H}_{2} \mathrm{O}_{2} \text {-induced } \\
\text { HepG2 cells. }\end{array}$ & [74] \\
\hline & Antiobesity & $\begin{array}{l}\text { Male C57BL/6J mice were fed a } \\
\text { high-fat diet with phloridzin } \\
(0.02 \%, w / w) \text { for } 16 \text { weeks. }\end{array}$ & $\begin{array}{c}\text { Supplementation of phloridzin } \\
\text { ameliorated not only insulin } \\
\text { resistance, but also obesity in } \\
\text { high-fat diet-induced obese } \\
\text { mice. }\end{array}$ & [76] \\
\hline & Hypolipidemic & $\begin{array}{c}\text { Phloridzin (purity }>98 \%, 20 \\
\mathrm{mg} / \mathrm{kg} \text { ) was administered in } \\
\text { normal saline solution by } \\
\text { intragastric administration for } 10 \\
\text { weeks. }\end{array}$ & $\begin{array}{l}\text { Phloridzin decreased body } \\
\text { weight gain and the levels of } \\
\text { glucose, blood total cholesterol } \\
\text { (TC) and blood triglycerides } \\
\text { (TG) in blood and, accordingly, } \\
\text { ameliorated hepatic damage of } \\
\text { type } 2 \text { diabetic mice. }\end{array}$ & [82] \\
\hline & Hepatoprotective & $\begin{array}{l}\text { Phloridzin ( } 40 \mathrm{mg} / \mathrm{kg} / \text { day) and } \\
\text { phloridzin ( } 80 \mathrm{mg} / \mathrm{kg} / \text { day) was } \\
\text { given orally for } 10 \text { consecutive } \\
\text { days. At the end of day } 3 \text { of the } \\
\text { experiment, the rats were } \\
\text { administered methotrexate. }\end{array}$ & $\begin{array}{l}\text { Phloridzin protected against } \\
\text { hepatic injury in rats mainly } \\
\text { through mitigation of oxidative } \\
\text { stress, inflammation and } \\
\text { apoptosis in hepatic tissues. }\end{array}$ & [83] \\
\hline & Cardioprotective & $\begin{array}{l}\text { Phloridzin (purity }>98 \% \text { ) was } \\
\text { dissolved in normal saline } \\
\text { solution and administered } \\
\text { intragastrically from week } 8 \text { to } \\
\text { week } 18 \text { without hypoglycemic } \\
\text { therapy. }\end{array}$ & $\begin{array}{l}\text { Phloridzin prevented the } \\
\text { development of diabetic } \\
\text { cardiomyopathy by regulating } \\
\text { the expression of key proteins in } \\
\text { these processes. }\end{array}$ & [91] \\
\hline & Antiaging & $\begin{array}{l}\text { Phloridzin }(4.0 \mathrm{~g}) \text { was isolated } \\
\text { from branches of dwarf apple } \\
\text { JM7 }(4.0 \mathrm{~kg}) \text {, and the chemical } \\
\text { structure was determined by } \\
\text { comparing }{ }^{1} \mathrm{H} \text { and }{ }^{13} \mathrm{C} \text { NMR } \\
\text { spectra. }\end{array}$ & $\begin{array}{l}\text { Phloridzin ( } 10 \mathrm{mM}, 30 \mathrm{mM}) \text { had } \\
\text { an antiaging effect on yeast by } \\
\text { increasing the activity of } \\
\text { superoxide dismutase (SOD) and } \\
\text { SIRT1. }\end{array}$ & [99] \\
\hline & Immunomodulatory & $\begin{array}{l}\text { Extracts from the fruits of Malus } \\
\text { baccata contained phloridzin } \\
\text { (relative content } 18.24 \% \text { ). }\end{array}$ & $\begin{array}{l}\text { The extracts had radioprotective } \\
\text { and immunomodulatory } \\
\text { activities. }\end{array}$ & [103] \\
\hline
\end{tabular}




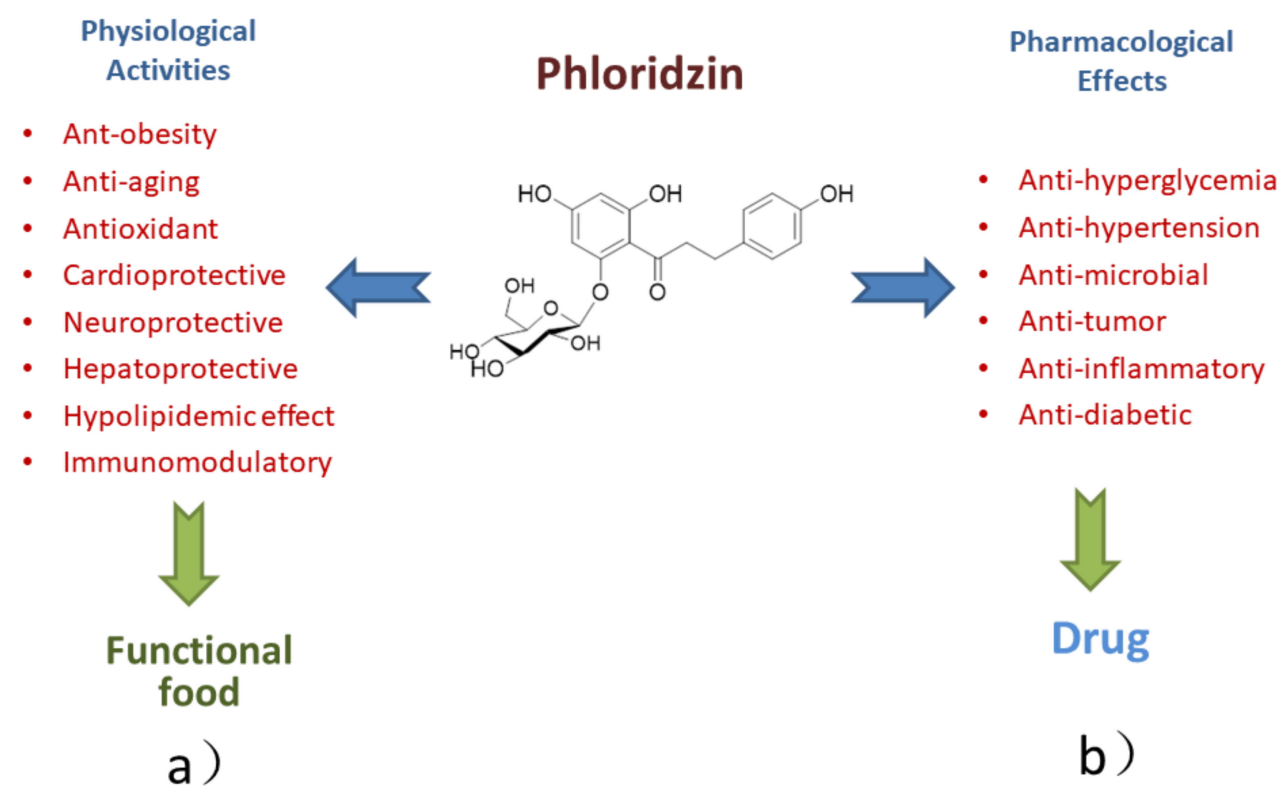

Figure 2. The potential applications and further use of phloridzin: (a) as an active compound in functional food and (b) as an active pharmaceutical ingredient in the pharmaceutical industry after optimization.

\section{Future Perspectives}

Phloridzin, a kind of natural organic compound, exists in numerous fruits and plants, and has been investigated for a long time because of its extensive bioactivities. Phloridzin was first used as a treatment for fever, infectious diseases and malaria about 180 years ago. Later, it played a key role in renal glucose reabsorption and hyperglycemia of diabetes. Phloridzin exerted an effective inhibitory activity on both SGLT1 and SGLT2, which made it widely used in medicine and physiological research. Although phloridzin holds potential for the treatment of diabetes, it has some limitations, including poor intestinal absorption, low bioavailability, rapid degradation by $\beta$-glucosidase and lactose-phloridzin-hydrolase and several adverse effects in clinical trials [108]. Although phloridzin itself was not developed as an antidiabetic drug, several phloridzin analogs (e.g., dapagliflozin and empagliflozin) show much more pharmacological viability, and these have been studied as therapeutic agents for diabetes [8]. In future, more investigations are needed on the various pharmacological mechanisms of phloridzin analogs and the biological activities of phloridzin metabolites.

Other studies suggest that phloridzin holds potential for food additives, cosmetics, beverages and food preservatives. Phloridzin is also a prospective biomarker for the consumption of phloridzin-containing foods. Phloridzin contributes to the characteristic taste of ciders, when its concentration is within the range of $3-16 \mathrm{~g} / \mathrm{L}$, while natural dimerized phloridzin plays important roles in the color formation of apple juices and ciders [109]. Therefore, there is a necessity for more studies to elucidate the toxicokinetics and toxicodynamics related to phloridzin and its metabolites in food applications. Moreover, how to apply drug packaging to phloridzin to improve its bioavailability should be paid more attention.

Funding: This research was supported by the Provincial Department of Education Natural Science Foundation of Yunnan (2020J0065).

Conflicts of Interest: The authors declare that no conflict of interest exists. 


\section{References}

1. Muceniece, R.; Namniece, J.; Nakurte, I.; Jekabsons, K.; Riekstina, U.; Jansone, B. Pharmacological research on natural substances in Latvia: Focus on lunasin, betulin, polyprenol and phlorizin. Pharmacol. Res. 2016, 113 Pt B, 760-770. [CrossRef]

2. Rios, J.L.; Recio, M.C. Medicinal plants and antimicrobial activity. J. Ethnopharmacol. 2005, 100, 80-84. [CrossRef]

3. Naghibi, F.; Esmaeili, S.; Abdullah, N.R.; Nateghpour, M.; Taghvai, M.; Kamkar, S.; Mosaddegh, M. In vitro and in vivo antimalarial evaluations of myrtle extract, a plant traditionally used for treatment of parasitic disorders. BioMed Res. Int. 2013, 2013, 316185. [CrossRef]

4. Lemma, M.T.; Ahmed, A.M.; Elhady, M.T.; Ngo, H.T.; Vu, T.L.; Sang, T.K.; Campos-Alberto, E.; Sayed, A.; Mizukami, S.; Na-Bangchang, K.; et al. Medicinal plants for in vitro antiplasmodial activities: A systematic review of literature. Parasitol. Int. 2017, 66, 713-720. [CrossRef]

5. Niederberger, K.E.; Tennant, D.R.; Bellion, P. Dietary intake of phloridzin from natural occurrence in foods. Br. J. Nutr. 2020, 123, 942-950. [CrossRef]

6. Gosch, C.; Halbwirth, H.; Stich, K. Phloridzin: Biosynthesis, distribution and physiological relevance in plants. Phytochemistry 2010, 71, 838-843. [CrossRef]

7. Ehrenkranz, J.R.; Lewis, N.G.; Kahn, C.R.; Roth, J. Phlorizin: A review. Diabetes/Metab. Res. Rev. 2005, 21, 31-38. [CrossRef]

8. White, J.R. Apple trees to sodium glucose co-transporter inhibitors: A review of SGLT2 inhibition. Clin. Diabetes 2010, 28, 5. [CrossRef]

9. Chasis, H.; Jolliffe, N.; Smith, H.W. The action of phlorizin on the excretion of glucose, xylose, sucrose, creatinine and urea by man. J. Clin. Investig. 1933, 12, 1083-1090. [CrossRef]

10. Moradi-Marjaneh, R.; Paseban, M.; Sahebkar, A. Natural products with SGLT2 inhibitory activity: Possibilities of application for the treatment of diabetes. Phytother. Res. PTR 2019, 33, 2518-2530. [CrossRef]

11. Choi, C.I. Sodium-Glucose Cotransporter 2 (SGLT2) inhibitors from natural products: Discovery of next-generation antihyperglycemic agents. Molecules 2016, 21, 1136. [CrossRef]

12. Blaschek, W. Natural products as lead compounds for Sodium Glucose Cotransporter (SGLT) inhibitors. Planta Med. 2017, 83, 985-993. [CrossRef]

13. Gosch, C.; Halbwirth, H.; Kuhn, J.; Miosic, S.; Stich, K. Biosynthesis of phloridzin in apple (Malus domestica Borkh.). Plant Sci. 2009, 176, 223-231. [CrossRef]

14. Zhou, K.; Hu, L.; Li, P.; Gong, X.; Ma, F. Genome-wide identification of glycosyltransferases converting phloretin to phloridzin in Malus species. Plant Sci. Int. J. Exp. Plant Biol. 2017, 265, 131-145. [CrossRef]

15. Zhou, K.; Hu, L.; Li, Y.; Chen, X.; Zhang, Z.; Liu, B.; Li, P.; Gong, X.; Ma, F. MdUGT88F1-mediated phloridzin biosynthesis regulates apple development and Valsa canker resistance. Plant Physiol. 2019, 180, 2290-2305. [CrossRef]

16. Dare, A.P.; Tomes, S.; Cooney, J.M.; Greenwood, D.R.; Hellens, R.P. The role of enoyl reductase genes in phloridzin biosynthesis in apple. Plant Physiol. Biochem. 2013, 72, 54-61. [CrossRef]

17. Lee, J.; Jung, E.; Kim, Y.S.; Park, D.; Toyama, K.; Date, A.; Lee, J. Phloridzin isolated from Acanthopanax senticosus promotes proliferation of alpha6 integrin (CD 49f) and beta1 integrin (CD29) enriched for a primary keratinocyte population through the ERK-mediated mTOR pathway. Arch. Dermatol. Res. 2013, 305, 747-754. [CrossRef]

18. Verardo, G.; Gorassini, A.; Fraternale, D. New triterpenic acids produced in callus culture from fruit pulp of Acca sellowiana (O. Berg) Burret. Food Res. Int. 2019, 119, 596-604. [CrossRef]

19. Stander, M.A.; Van Wyk, B.-E.; Taylor, M.J.C.; Long, H.S. Analysis of phenolic compounds in rooibos tea (Aspalathus linearis) with a comparison of flavonoid-based compounds in natural populations of plants from different regions. J. Agric. Food Chem. 2017, 65, 10270-10281. [CrossRef]

20. Belwal, T.; Giri, L.; Bhatt, I.D.; Rawal, R.S.; Pande, V. An improved method for extraction of nutraceutically important polyphenolics from Berberis jaeschkeana C.K. Schneid. fruits. Food Chem. 2017, 230, 657-666. [CrossRef]

21. Cho, J.Y.; Ji, S.H.; Moon, J.H.; Lee, K.H.; Jung, K.H.; Park, K.H. A novel benzoyl glucoside and phenolic compounds from the leaves of Camellia japonica. Food Sci. Biotechnol. 2008, 17, 1060-1065.

22. Zhang, X.; Mei, X.; Wang, Z.; Wu, J.; Liu, G.; Hu, H.; Li, Q. Chemical fingerprint and quantitative analysis for the quality evaluation of Docynia dcne leaves by high-performance liquid chromatography coupled with chemometrics analysis. J. Chromatogr. Sci. 2018, 56, 575-581. [CrossRef]

23. Zhang, X.Y.; Yi, K.; Chen, J.; Li, R.P.; Xie, J.; Jin, Y.; Mei, X.R.; Li, Y.J.; Liu, G.; Wang, Z.G. Purified phlorizin from DocynIa Indica (Wall.) Decne by HSCCC, compared with whole extract, phlorizin and non-phlorizin fragment ameliorate obesity, insulin resistance, and improves intestinal barrier function in high-fat-diet-fed mice. Molecules 2018, 23, 2701. [CrossRef]

24. Choi, H.R.; Nam, K.M.; Lee, H.S.; Yang, S.H.; Kim, Y.S.; Lee, J.; Date, A.; Toyama, K.; Park, K.C. Phlorizin, an active ingredient of Eleutherococcus senticosus, increases proliferative potential of keratinocytes with inhibition of MiR135b and increased expression of type IV collagen. Oxidative Med. Cell. Longev. 2016, 2016, 3859721. [CrossRef]

25. Hilt, P.; Schieber, A.; Yildirim, C.; Arnold, G.; Klaiber, I.; Conrad, J.; Beifuss, U.; Carle, R. Detection of phloridzin in strawberries (Fragaria $x$ ananassa Duch.) by HPLC-PDA-MS/MS and NMR spectroscopy. J. Agric. Food Chem. 2003, 51, 2896-2899. [CrossRef]

26. Lee, C.C.; Dudonne, S.; Dube, P.; Desjardins, Y.; Kim, J.H.; Kim, J.S.; Kim, J.E.; Park, J.H.Y.; Lee, K.W.; Lee, C.Y. Comprehensive phenolic composition analysis and evaluation of Yak-Kong soybean (Glycine max) for the prevention of atherosclerosis. Food Chem. 2017, 234, 486-493. [CrossRef] 
27. Cichewicz, R.H.; Nair, M.G. Isolation and Characterization of stelladerol, a new antioxidant naphthalene glycoside, and other antioxidant glycosides from edible daylily (Hemerocallis) flowers. J. Agric. Food Chem. 2002, 50, 87-91. [CrossRef]

28. Altunkaya, A.; Gökmen, V. Effect of various anti-browning agents on phenolic compounds profile of fresh lettuce (L. sativa). Food Chem. 2009, 117, 122-126. [CrossRef]

29. Chen, Y.; Yin, L.Z.; Zhao, L.; Shu, G.; Yuan, Z.X.; Fu, H.L.; Lv, C.; Lin, J.C. Optimization of the ultrasound-assisted extraction of antioxidant phloridzin from Lithocarpus polystachyus Rehd. using response surface methodology. J. Sep. Sci. 2017, 40, $4329-4337$. [CrossRef]

30. Sun, Y.; Li, W.; Liu, Z. Preparative isolation, quantification and antioxidant activity of dihydrochalcones from Sweet Tea (Lithocarpus polystachyus Rehd.). J. Chromatogr. B Anal. Technol. Biomed. Life Sci. 2015, 1002, 372-378. [CrossRef]

31. Li, X.; Zhao, Y.; Hou, S.; Huang, S.; Yang, W.; Lai, X.; Zeng, X. Identification of the bioactive components of orally administered Lithocarpus polystachyus Rehd and their metabolites in rats by liquid chromatography coupled to LTQ Orbitrap mass spectrometry. J. Chromatogr. B Anal. Technol. Biomed. Life Sci. 2014, 962, 37-43. [CrossRef]

32. Dong, H.; Ning, Z.; Yu, L.; Li, L.; Lin, L.; Huang, J. Preparative separation and identification of the flavonoid phlorhizin from the crude extract of Lithocarpus polystachyus Rehd. Molecules 2007, 12, 552-562. [CrossRef]

33. Lin, L.-Z.; Mukhopadhyay, S.; Robbins, R.J.; Harnly, J.M. Identification and quantification of flavonoids of Mexican oregano (Lippia graveolens) by LC-DAD-ESI/MS analysis. J. Food Compos. Anal. 2007, 20, 361-369. [CrossRef]

34. Ma, Z.; Huang, Y.; Huang, W.; Feng, X.; Yang, F.; Li, D. Separation, identification, and antioxidant activity of polyphenols from lotus seed epicarp. Molecules 2019, 24, 4007. [CrossRef]

35. Xu, M.; Jin, Z.; Ohm, J.B.; Schwarz, P.; Rao, J.; Chen, B. Effect of germination time on antioxidative activity and composition of yellow pea soluble free and polar soluble bound phenolic compounds. Food Funct. 2019, 10, 6840-6850. [CrossRef]

36. Sun, Y.; Gu, S.; Guo, L.; Xia, X.; Zhang, H.; Wang, J. Preparative separation of five flavones from flowers of Polygonum cuspidatum by high-speed countercurrent chromatography. J. Sep. Sci. 2014, 37, 1703-1709. [CrossRef]

37. Zhang, X.; Su, M.; Du, J.; Zhou, H.; Li, X.; Li, X.; Ye, Z. Comparison of phytochemical differences of the pulp of different peach [Prunus persica (L.) Batsch] cultivars with alpha-glucosidase inhibitory activity variations in china using UPLC-Q-TOF/MS. Molecules 2019, 24, 1968. [CrossRef]

38. Rojas-Garbanzo, C.; Zimmermann, B.F.; Schulze-Kaysers, N.; Schieber, A. Characterization of phenolic and other polar compounds in peel and flesh of pink guava (Psidium guajava L. cv. 'Criolla') by ultra-high performance liquid chromatography with diode array and mass spectrometric detection. Food Res. Int. 2017, 100 Pt 3, 445-453. [CrossRef]

39. Poyrazoğlu, E.; Gökmen, V.; Artık, N. Organic acids and phenolic compounds in pomegranates (Punica granatum L.) Grown in Turkey. J. Food Compos. Anal. 2002, 15, 567-575. [CrossRef]

40. Prakash, O.; Baskaran, R.; Kudachikar, V.B. Characterization, quantification of free, esterified and bound phenolics in Kainth (Pyrus pashia Buch.-Ham. Ex D.Don) fruit pulp by UPLC-ESI-HRMS/MS and evaluation of their antioxidant activity. Food Chem. 2019, 299, 125114. [CrossRef]

41. Hvattum, E. Determination of phenolic compounds in rose hip (Rosa canina) using liquid chromatography coupled to electrospray ionisation tandem mass spectrometry and diode-array detection. Rapid Commun. Mass Spectrom. 2002, 16, 655-662. [CrossRef]

42. Paudel, L.; Wyzgoski, F.J.; Scheerens, J.C.; Chanon, A.M.; Reese, R.N.; Smiljanic, D.; Wesdemiotis, C.; Blakeslee, J.J.; Riedl, K.M.; Rinaldi, P.L. Nonanthocyanin secondary metabolites of black raspberry (Rubus occidentalis L.) fruits: Identification by HPLC-DAD, NMR, HPLC-ESI-MS, and ESI-MS/MS analyses. J. Agric. Food Chem. 2013, 61, 12032-12043. [CrossRef]

43. Martinez Bueno, M.J.; Diaz-Galiano, F.J.; Rajski, L.; Cutillas, V.; Fernandez-Alba, A.R. A non-targeted metabolomic approach to identify food markers to support discrimination between organic and conventional tomato crops. J. Chromatogr. A 2018, 1546, 66-76. [CrossRef]

44. Aguiniga-Sanchez, I.; Cadena-Iniguez, J.; Santiago-Osorio, E.; Gomez-Garcia, G.; Mendoza-Nunez, V.M.; Rosado-Perez, J.; Ruiz-Ramos, M.; Cisneros-Solano, V.M.; Ledesma-Martinez, E.; Delgado-Bordonave, A.J.; et al. Chemical analyses and in vitro and in vivo toxicity of fruit methanol extract of Sechium edule var. nigrum spinosum. Pharm. Biol. 2017, 55, 1638-1645. [CrossRef]

45. Bhullar, K.S.; Rupasinghe, H.P. Antioxidant and cytoprotective properties of partridgeberry polyphenols. Food Chem. 2015, 168, 595-605. [CrossRef]

46. Turner, A.; Chen, S.-N.; Joike, M.K.; Pendland, S.L.; Pauli, G.F.; Farnsworth, N.R. Inhibition of Uropathogenic Escherichia coli by cranberry juice: A new antiadherence assay. J. Agric. Food Chem. 2005, 53, 8940-8947. [CrossRef]

47. Alberti, A.; Zielinski, A.A.; Zardo, D.M.; Demiate, I.M.; Nogueira, A.; Mafra, L.I. Optimisation of the extraction of phenolic compounds from apples using response surface methodology. Food Chem. 2014, 149, 151-158. [CrossRef]

48. Zhang, Z.; Liu, F.; He, C.; Yu, Y.; Wang, M. Optimization of ultrasonic-assisted aqueous two-phase extraction of phloridzin from malus Micromalus Makino with ethanol/ammonia sulfate system. J. Food Sci. 2017, 82, 2944-2953. [CrossRef]

49. Fromm, M.; Bayha, S.; Carle, R.; Kammerer, D.R. Characterization and quantitation of low and high molecular weight phenolic compounds in apple seeds. J. Agric. Food Chem. 2012, 60, 1232-1242. [CrossRef]

50. Sun, L.; Guo, Y.; Fu, C.; Li, J.; Li, Z. Simultaneous separation and purification of total polyphenols, chlorogenic acid and phlorizin from thinned young apples. Food Chem. 2013, 136, 1022-1029. [CrossRef]

51. Sun, L.; Liu, D.; Sun, J.; Yang, X.; Fu, M.; Guo, Y. Simultaneous separation and purification of chlorogenic acid, epicatechin, hyperoside and phlorizin from thinned young Qinguan apples by successive use of polyethylene and polyamide resins. Food Chem. 2017, 230, 362-371. [CrossRef] 
52. Liang, X.; Zhang, Y.; Chen, W.; Cai, P.; Zhang, S.; Chen, X.; Shi, S. High-speed counter-current chromatography coupled online to high performance liquid chromatography-diode array detector-mass spectrometry for purification, analysis and identification of target compounds from natural products. J. Chromatogr. A 2015, 1385, 69-76. [CrossRef]

53. Gao, D.; Wang, D.D.; Fu, Q.F.; Wang, L.J.; Zhang, K.L.; Yang, F.Q.; Xia, Z.N. Preparation and evaluation of magnetic molecularly imprinted polymers for the specific enrichment of phloridzin. Talanta 2018, 178, 299-307. [CrossRef]

54. Li, H.; Hou, G.; Li, Y.; Zhao, F.; Cong, W.; Wang, C. Preparative separation of phloridzin from apple leaves using macroporous resins followed by preparative high-performance liquid chromatography. J. Sep. Sci. 2018, 41, 3918-3924. [CrossRef]

55. Rossetti, L.; Smith, D.; Shulman, G.I.; Papachristou, D.; DeFronzo, R.A. Correction of hyperglycemia with phlorizin normalizes tissue sensitivity to insulin in diabetic rats. J. Clin. Investig. 1987, 79, 1510-1515. [CrossRef]

56. Zhao, H.; Yakar, S.; Gavrilova, O.; Sun, H.; Zhang, Y.; Kim, H.; Setser, J.; Jou, W.; LeRoith, D. Phloridzin improves hyperglycemia but not hepatic insulin resistance in a transgenic mouse model of type 2 diabetes. Diabetes 2004, 53, 2901-2909. [CrossRef]

57. Boccia, M.M.; Kopf, S.R.; Baratti, C.M. Phlorizin, a competitive inhibitor of glucose transport, facilitates memory storage in mice. Neurobiol. Learn. Mem. 1999, 71, 104-112. [CrossRef]

58. Burcelin, R.; Mrejen, C.; Decaux, J.F.; De Mouzon, S.H.; Girard, J.; Charron, M.J. In vivo and in vitro regulation of hepatic glucagon receptor mRNA concentration by glucose metabolism. J. Biol. Chem. 1998, 273, 8088-8093. [CrossRef]

59. Yamaguchi, K.; Kato, M.; Suzuki, M.; Asanuma, K.; Aso, Y.; Ikeda, S.; Ishigai, M. Pharmacokinetic and pharmacodynamic modeling of the effect of an sodium-glucose cotransporter inhibitor, phlorizin, on renal glucose transport in rats. Drug Metab. Dispos. Biol. Fate Chem. 2011, 39, 1801-1807. [CrossRef]

60. Malatiali, S.; Francis, I.; Barac-Nieto, M. Phlorizin prevents glomerular hyperfiltration but not hypertrophy in diabetic rats. Exp. Diabetes Res. 2008, 2008, 305403. [CrossRef]

61. Masumoto, S.; Akimoto, Y.; Oike, H.; Kobori, M. Dietary phloridzin reduces blood glucose levels and reverses Sglt1 expression in the small intestine in streptozotocin-induced diabetic mice. J. Agric. Food Chem. 2009, 57, 4651-4656. [CrossRef]

62. Osorio, H.; Bautista, R.; Rios, A.; Franco, M.; Arellano, A.; Vargas-Robles, H.; Romo, E.; Escalante, B. Effect of phlorizin on SGLT2 expression in the kidney of diabetic rats. J. Nephrol. 2010, 23, 541-546. [PubMed]

63. Kobori, M.; Masumoto, S.; Akimoto, Y.; Oike, H. Phloridzin reduces blood glucose levels and alters hepatic gene expression in normal BALB/c mice. Food Chem. Toxicol. Int. J. Publ. Br. Ind. Biol. Res. Assoc. 2012, 50, 2547-2553. [CrossRef]

64. Najafian, M.; Jahromi, M.Z.; Nowroznejhad, M.J.; Khajeaian, P.; Kargar, M.M.; Sadeghi, M.; Arasteh, A. Phloridzin reduces blood glucose levels and improves lipids metabolism in streptozotocin-induced diabetic rats. Mol. Biol. Rep. 2012, 39, 5299-5306. [CrossRef]

65. Makarova, E.; Gornas, P.; Konrade, I.; Tirzite, D.; Cirule, H.; Gulbe, A.; Pugajeva, I.; Seglina, D.; Dambrova, M. Acute antihyperglycaemic effects of an unripe apple preparation containing phlorizin in healthy volunteers: A preliminary study. J. Sci. Food Agric. 2015, 95, 560-568. [CrossRef]

66. Mei, X.; Zhang, X.; Wang, Z.; Gao, Z.; Liu, G.; Hu, H.; Zou, L.; Li, X. Insulin sensitivity-enhancing activity of phlorizin is associated with lipopolysaccharide decrease and gut microbiota changes in obese and type 2 diabetes (db/db) mice. J. Agric. Food Chem. 2016, 64, 7502-7511. [CrossRef]

67. Wang, J.; Huang, Y.; Li, K.; Chen, Y.; Vanegas, D.; McLamore, E.S.; Shen, Y. Leaf Extract from Lithocarpus polystachyus Rehd. promote glycogen synthesis in T2DM mice. PLoS ONE 2016, 11, e0166557. [CrossRef]

68. Lv, Q.; Lin, Y.; Tan, Z.; Jiang, B.; Xu, L.; Ren, H.; Tai, W.C.; Chan, C.O.; Lee, C.S.; Gu, Z.; et al. Dihydrochalcone-derived polyphenols from tea crab apple (Malus hupehensis) and their inhibitory effects on alpha-glucosidase in vitro. Food Funct. 2019, 10, 2881-2887. [CrossRef]

69. Xiao, Z.; Zhang, Y.; Chen, X.; Wang, Y.; Chen, W.; Xu, Q.; Li, P.; Ma, F. Extraction, identification, and antioxidant and anticancer tests of seven dihydrochalcones from Malus 'Red Splendor' fruit. Food Chem. 2017, 231, 324-331. [CrossRef]

70. Liaudanskas, M.; Viskelis, P.; Raudonis, R.; Kviklys, D.; Uselis, N.; Janulis, V. Phenolic composition and antioxidant activity of Malus domestica leaves. Sci. World J. 2014, 2014, 306217. [CrossRef]

71. Rupasinghe, H.P.V.; Yasmin, A. Inhibition of oxidation of aqueous emulsions of omega-3 fatty acids and fish oil by phloretin and phloridzin. Molecules 2010, 15, 251-257. [CrossRef]

72. Thilakarathna, S.H.; Rupasinghe, H.P.; Needs, P.W. Apple peel bioactive rich extracts effectively inhibit in vitro human LDL cholesterol oxidation. Food Chem. 2013, 138, 463-470. [CrossRef]

73. Wang, H.; Sun, Z.; Liu, D.; Li, X.; Rehman, R.U.; Wang, H.; Wu, Z. Apple phlorizin attenuates oxidative stress in Drosophila melanogaster. J. Food Biochem. 2019, 43, e12744. [CrossRef]

74. Fan, Z.; Wang, Y.; Yang, M.; Cao, J.; Khan, A.; Cheng, G. UHPLC-ESI-HRMS/MS analysis on phenolic compositions of different E Se tea extracts and their antioxidant and cytoprotective activities. Food Chem. 2020, 318, 126512. [CrossRef]

75. Sun, L.; Sun, J.; Thavaraj, P.; Yang, X.; Guo, Y. Effects of thinned young apple polyphenols on the quality of grass carp (Ctenopharyngodon idellus) surimi during cold storage. Food Chem. 2017, 224, 372-381. [CrossRef]

76. Shin, S.K.; Cho, S.J.; Jung, U.J.; Ryu, R.; Choi, M.S. Phlorizin supplementation attenuates obesity, inflammation, and hyperglycemia in diet-induced obese mice fed a high-fat diet. Nutrients 2016, 8, 92. [CrossRef]

77. Zhao, Y.; Liu, C.; Lai, X.; Hou, S.; Zeng, X.; Li, X. Immunomodulatory activities of phlorizin metabolites in lipopolysaccharidestimulated RAW264.7 cells. Biomed. Pharmacother. 2017, 91, 49-53. [CrossRef] 
78. Zielinska, D.; Laparra-Llopis, J.M.; Zielinski, H.; Szawara-Nowak, D.; Gimenez-Bastida, J.A. Role of apple phytochemicals, phloretin and phloridzin, in modulating processes related to intestinal inflammation. Nutrients 2019, 11, 1173. [CrossRef]

79. Chang, W.T.; Huang, W.C.; Liou, C.J. Evaluation of the anti-inflammatory effects of phloretin and phlorizin in lipopolysaccharidestimulated mouse macrophages. Food Chem. 2012, 134, 972-979. [CrossRef]

80. Zhai, Y.; Dang, Y.; Gao, W.; Zhang, Y.; Xu, P.; Gu, J.; Ye, X. P38 and JNK signal pathways are involved in the regulation of phlorizin against UVB-induced skin damage. Exp. Dermatol. 2015, 24, 275-279. [CrossRef]

81. Tian, Y.; Gao, L.; Guo, Y.; Xu, Y. Short-term phlorizin treatment attenuates adipose tissue inflammation without alerting obesity in high-fat diet fed mice. J. Food Biochem. 2017, 41, e12407. [CrossRef]

82. Lu, W.D.; Li, B.Y.; Yu, F.; Cai, Q.; Zhang, Z.; Yin, M.; Gao, H.Q. Quantitative proteomics study on the protective mechanism of phlorizin on hepatic damage in diabetic db/db mice. Mol. Med. Rep. 2012, 5, 1285-1294. [PubMed]

83. Khalifa, M.M.A.; Bakr, A.G.; Osman, A.T. Protective effects of phloridzin against methotrexate-induced liver toxicity in rats. Biomed. Pharmacother. 2017, 95, 529-535. [CrossRef]

84. Illam, S.P.; Hussain, A.; Elizabeth, A.; Narayanankutty, A.; Raghavamenon, A.C. Natural combination of phenolic glycosides from fruits resists pro-oxidant insults to colon cells and enhances intrinsic antioxidant status in mice. Toxicol. Rep. 2019, 6, 703-711. [CrossRef]

85. Wang, H.; Cheng, J.; Wang, H.; Wang, M.; Zhao, J.; Wu, Z. Protective effect of apple phlorizin on hydrogen peroxide-induced cell damage in HepG2 cells. J. Food Biochem. 2019, 43, e13052. [CrossRef]

86. David-Silva, A.; Esteves, J.V.; Morais, M.; Freitas, H.S.; Zorn, T.M.; Correa-Giannella, M.L.; Machado, U.F. Dual SGLT1/SGLT2 inhibitor phlorizin ameliorates non-alcoholic fatty liver disease and hepatic glucose production in type 2 diabetic mice. Diabetes Metab. Syndr. Obes. Targets Ther. 2020, 13, 739-751. [CrossRef]

87. Qin, X.; Xing, Y.F.; Zhou, Z.; Yao, Y. Dihydrochalcone compounds isolated from crabapple leaves showed anticancer effects on human cancer cell lines. Molecules 2015, 20, 21193-21203. [CrossRef]

88. Sowa, A.; Zgorka, G.; Szykula, A.; Franiczek, R.; Zbikowska, B.; Gamian, A.; Sroka, Z. Analysis of polyphenolic compounds in extracts from leaves of some Malus domestica cultivars: Antiradical and antimicrobial analysis of these extracts. BioMed Res. Int. 2016, 2016, 6705431. [CrossRef]

89. Lopes, L.A.A.; Dos Santos Rodrigues, J.B.; Magnani, M.; De Souza, E.L.; De Siqueira-Junior, J.P. Inhibitory effects of flavonoids on biofilm formation by Staphylococcus aureus that overexpresses efflux protein genes. Microb. Pathog. 2017, 107, 193-197. [CrossRef]

90. Oleszek, M.; Pecio, L.; Kozachok, S.; Lachowska-Filipiuk, Z.; Oszust, K.; Frac, M. Phytochemicals of apple pomace as prospect bio-fungicide agents against mycotoxigenic fungal species-in vitro experiments. Toxins 2019, 11, 361. [CrossRef]

91. Cai, Q.; Li, B.; Yu, F.; Lu, W.; Zhang, Z.; Yin, M.; Gao, H. Investigation of the protective effects of phlorizin on diabetic cardiomyopathy in $\mathrm{db} / \mathrm{db}$ mice by quantitative proteomics. J. Diabetes Res. 2013, 2013, 263845. [CrossRef]

92. Hirose, M.; Shibazaki, T.; Nakada, T.; Kashihara, T.; Yano, S.; Okamoto, Y.; Isaji, M.; Matsushita, N.; Taira, E.; Yamada, M. Phlorizin prevents electrically-induced ventricular tachyarrhythmia during ischemia in Langendorff-perfused guinea-pig hearts. Biol. Pharm. Bull. 2014, 37, 1168-1176. [CrossRef]

93. Puel, C.; Quintin, A.; Mathey, J.; Obled, C.; Davicco, M.J.; Lebecque, P.; Kati-Coulibaly, S.; Horcajada, M.N.; Coxam, V. Prevention of bone loss by phloridzin, an apple polyphenol, in ovariectomized rats under inflammation conditions. Calcif. Tissue Int. 2005, 77, 311-318. [CrossRef]

94. Antika, L.D.; Lee, E.J.; Kim, Y.H.; Kang, M.K.; Park, S.H.; Kim, D.Y.; Oh, H.; Choi, Y.J.; Kang, Y.H. Dietary phlorizin enhances osteoblastogenic bone formation through enhancing beta-catenin activity via GSK-3beta inhibition in a model of senile osteoporosis. J. Nutr. Biochem. 2017, 49, 42-52. [CrossRef]

95. Londzin, P.; Siudak, S.; Cegiela, U.; Pytlik, M.; Janas, A.; Waligora, A.; Folwarczna, J. Phloridzin, an apple polyphenol, exerted unfavorable effects on bone and muscle in an experimental model of type 2 diabetes in rats. Nutrients 2018, 10, 1701. [CrossRef]

96. Andlauer, W.; Kolb, J.; Furst, P. Phloridzin improves absorption of genistin in isolated rat small intestine. Clin. Nutr. 2004, 23, 989-995. [CrossRef]

97. Jung, E.; Lee, J.; Huh, S.; Lee, J.; Kim, Y.S.; Kim, G.; Park, D. Phloridzin-induced melanogenesis is mediated by the cAMP signaling pathway. Food Chem. Toxicol. Int. J. Publ. Br. Ind. Biol. Res. Assoc. 2009, 47, 2436-2440. [CrossRef]

98. Gatidis, S.; Meier, A.; Jilani, K.; Lang, E.; Zelenak, C.; Qadri, S.M.; Lang, F. Phlorhizin protects against erythrocyte cell membrane scrambling. J. Agric. Food Chem. 2011, 59, 8524-8530. [CrossRef]

99. Xiang, L.; Sun, K.; Lu, J.; Weng, Y.; Taoka, A.; Sakagami, Y.; Qi, J. Anti-aging effects of phloridzin, an apple polyphenol, on yeast via the SOD and Sir2 genes. Biosci. Biotechnol. Biochem. 2011, 75, 854-858. [CrossRef]

100. Wang, X.; Zhang, S.; Liu, Y.; Spichtig, D.; Kapoor, S.; Koepsell, H.; Mohebbi, N.; Segerer, S.; Serra, A.L.; Rodriguez, D.; et al. Targeting of sodium-glucose cotransporters with phlorizin inhibits polycystic kidney disease progression in Han: SPRD rats. Kidney Int. 2013, 84, 962-968. [CrossRef]

101. Pei, F.; Li, B.Y.; Zhang, Z.; Yu, F.; Li, X.L.; Lu, W.D.; Cai, Q.; Gao, H.Q.; Shen, L. Beneficial effects of phlorizin on diabetic nephropathy in diabetic $\mathrm{db} / \mathrm{db}$ mice. J. Diabetes Its Complicat. 2014, 28, 596-603. [CrossRef]

102. Wang, G.E.; Li, Y.F.; Wu, Y.P.; Tsoi, B.; Zhang, S.J.; Cao, L.F.; Kurihara, H.; He, R.R. Phloridzin improves lipoprotein lipase activity in stress-loaded mice via AMPK phosphorylation. Int. J. Food Sci. Nutr. 2014, 65, 874-880. [CrossRef] 
103. Wang, L.; Li, X.; Wang, Z. Whole body radioprotective effect of phenolic extracts from the fruits of Malus baccata (Linn.) Borkh. Food Funct. 2016, 7, 975-981. [CrossRef]

104. Kanda, H.; Kaneda, T.; Kawaguchi, A.; Sasaki, N.; Tajima, T.; Urakawa, N.; Shimizu, K.; Suzuki, H. Phloridzin inhibits high $\mathrm{K}(+)$-induced contraction via the inhibition of sodium: Glucose cotransporter 1 in rat ileum. J. Vet. Med. Sci. 2017, 79, 593-601. [CrossRef]

105. Li, C.Y.; Wang, L.X.; Dong, S.S.; Hong, Y.; Zhou, X.H.; Zheng, W.W.; Zheng, C. Phlorizin exerts direct protective effects on palmitic Acid (PA)-induced endothelial dysfunction by activating the PI3K/AKT/eNOS signaling pathway and increasing the levels of Nitric Oxide (NO). Med. Sci. Monit. Basic Res. 2018, 24, 1-9. [CrossRef]

106. Kumar, S.; Sinha, K.; Sharma, R.; Purohit, R.; Padwad, Y. Phloretin and phloridzin improve insulin sensitivity and enhance glucose uptake by subverting PPARgamma/Cdk5 interaction in differentiated adipocytes. Exp. Cell Res. 2019, $383,111480$. [CrossRef]

107. Park, J.; Kwon, O.; Cho, S.Y.; Cho, M.C.; Paick, J.S.; Kim, S.W. Comparison of improving effects for diabetic erectile dysfunction according to the anti-glycemic agents: Phlorizin and insulin. World J. Men's Health 2019, 37, 210-218. [CrossRef]

108. Mather, A.; Pollock, C. Renal glucose transporters: Novel targets for hyperglycemia management. Nat. Rev. Nephrol. 2010, 6, 307-311. [CrossRef]

109. Ridgway, T.; Tucker, G. Phloridzin derivatives; food additives/chemopreventative drugs of the future. Biochem. Soc. Trans. 1997, 25, 109S. [CrossRef] 